\title{
PENGERINGAN TERASI LOKAL KARAWANG : SINAR MATAHARI - TRAY DRYER
}

\author{
Dessy Agustina Sari ${ }^{1}$, Azafilmi Hakiim² ${ }^{2}$ Sukanta $^{3}$ \\ Prodi Teknik Elektro, Universitas Singaperbangsa Karawang \\ Kabupaten Karawang, Provinsi Jawa Barat, Indonesia \\ ${ }^{2,3}$ Prodi Teknik Industri, Universitas Singaperbangsa Karawang \\ Kabupaten Karawang, Provinsi Jawa Barat, Indonesia \\ e-mail: dessy.agustina8@gmail.com
}

\begin{abstract}
Abstrak
Pembuatan terasi lokal Karawang masih memanfaatkan ketersediaan sinar matahari. Luas area penjemuran menjadi sorotan umum bila pengunjung melewati pemukiman TPI Ciparage. Udang rebon dihampar di pekarangan rumah pengrajin terasi. Ketidakbersihan proses yang berlangsung dan fluktuatifnya udara panas menginisasi kebutuhan teknologi sehingga saat ini dapat dijumpai pengering rak. Penggunaan tray dryer mulai dari bahan baku hingga terbentuknya produk terasi mampu mengurangi luas ruang pengeringan dan juga udara panas tersirkulasi secara merata. Perbandingan penurunan masa bahan per waktu antara sinar matahari dan alat tersebut belum memberikan hasil yang signifikan berbeda, tetapi terlihat nyata pada penampakan produk terasi. Pengoptimalan penggunaan seluruh rak dapat meningkatkan kuantitas produk terasi dan langkah mengatasi luas ruang pengering.
\end{abstract}

Kata kunci: sinar matahari, terasi, tray dryer, udang rebon

\begin{abstract}
Shrimp paste processing from Karawang still used the availability of the sun shine. Wide area of drying was being general highlight if visitor took around TPI Ciparage's residence. Rebon shrimp was put in the producer's yard. No hygiene on progress process and fluctuations of hot air pushed a technology. So nowadays researcher could have plan through tray dryer. Using of this machine from raw material until the shrimp pasted product could decrease the drying area and also hot air could be circulated evenly. The result showed that the sample mass by sun and tray dryer did not give a significantly difference, but not for the product's sightings. Optimization of all of tray on the machine could improve the quantity of shrimp paste product and a way solved the wide area of drying.
\end{abstract}

Keywords : rebon shrimp, shrimp pasted, sun, tray dryer

\section{PENDAHULUAN}

Pantai Ciparage merupakan salah
satu lokasi yang memiliki Tempat Pelelangan Ikan (TPI) sebagai tempat berkumpulnya hasil para nelayan sekitar. Pantai tersebut merupakan salah lokasi ekonomi bagi warga Pantai Utara Laut Jawa (Sulistiyono, 2014). Salah satu hasil tangkapan lautnya adalah udang rebon yang kerap dinanti para pengrajin terasi.

Bahan baku tersebut terkadang didapatkan dalam keadaan bersih bahkan semikotor dari nelayan. Penjajaan hasil tangkapan di TPI ditunjukkan Gambar 1 berikut. Selanjutnya, ketersediaan bahan baku yang ditemui peneliti memiliki dua variasi nilai jual yaitu kualitas rendah dimana satu bakul seharga Rp. 40.000 45.000,-. Peningkatan penampilan udang rebon yang tampak lebih bersih mampu mencapai Rp. 60.000,-. Pengotor seperti batu apung, campuran udang sedang dan ikan, serta beberapa sampah menjadikan proses penyiapan bahan baku berdurasi lebih lama. 
Resep pembuatan terasi diturunkan dari generasi ke generasi. Masyarakat Indonesia umumnya memanfaatkannya sebagai pemberi cita rasa sambal. Hal ini pula yang dijalankan oleh warga Sumenep yang menggiatkan pengembangan pembuatan terasi udang sebagai produk lokal khas daerah setempat (Maflahah, 2013). Kemudian, produk terasi lainnya seperti Belacan mampu menjadi produk inovasi lokal dari kabupaten Belitung (Sudaryanto, 2013).

Proses bahan baku hingga menjadi terasi membutuhkan waktu selama satu minggu dengan catatan kondisi lingkungan cerah. Hal ini diadopsi dari petani terasi desa Kalong Kalen, kecamatan Tempuran. Sinar matahari menjadi sorotan utama bagi para pelaku kegiatan tersebut. Penjemuran dilakukan di halaman rumah dengan beralaskan bahan bambu, dan terkadang lokasi bersebelahan dengan kandang ternak. Pengeringan bahan baku disajikan ke dalam Gambar 2 berikut.

Penyimpanan bahan dari hari ke hari juga tidak dihiraukan sehingga terjadinya kontak antara bahan dengan hewan seperti lalat (menggunakan karung beras). Produksi bersih terasi mulai dijalankan oleh warga pesisir Bontang untuk meningkatkan produktivitas dan memberikan tingkat efisiensi yang lebih dari penggunaan bahan baku, energi dan air sehingga efektif dalam menekan biaya produksi (Ma'ruf, Sukarti, Purnamasari, \& Sulistianto, 2013).

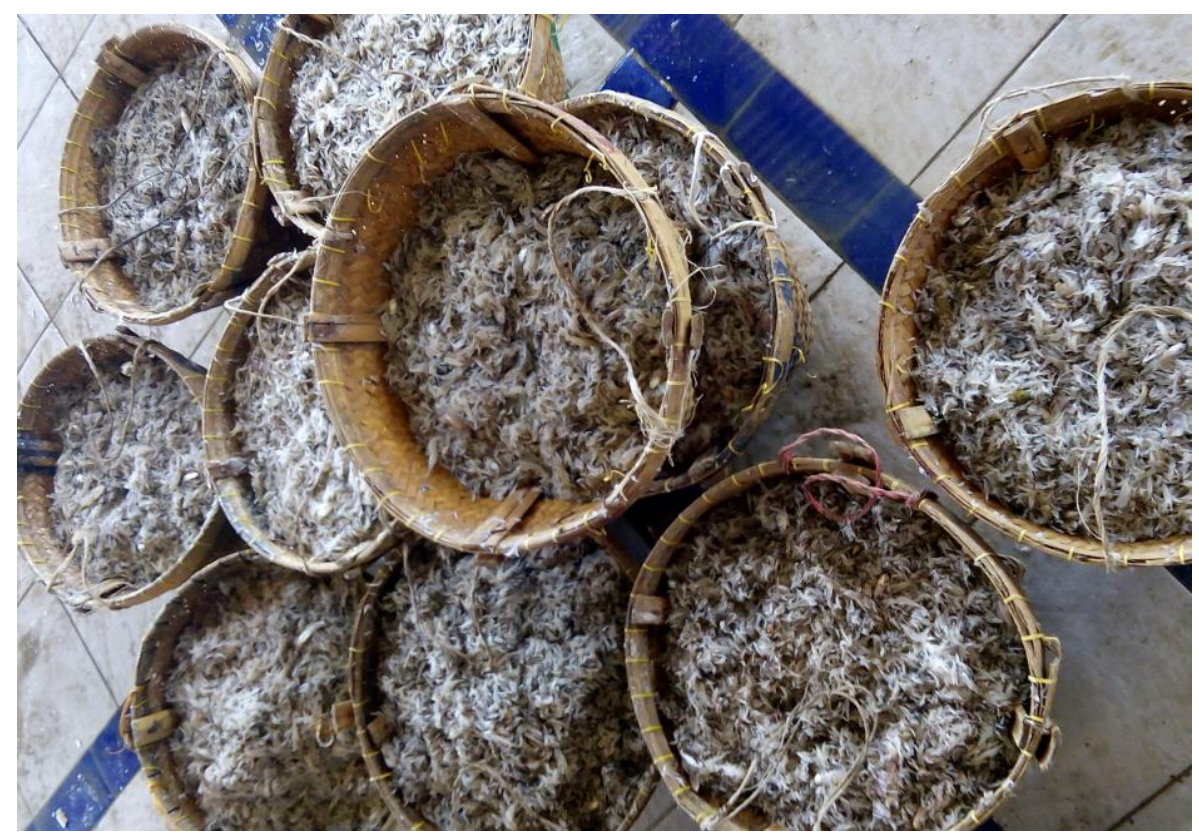

Gambar 1. Udang rebon basah

Selain itu, serangkaian kegiatan pembuatan terasi lokal Karawang masih menggunakan peralatan sederhana. Sedangkan, di lingkungan Pantai Teleng Kota Pacitan, pengrajin tetap menerapkan produksi terasi (penjemuran) secara kovensional, namun keberadaan mesin penggiling terasi mulai dihadirkan sebagai pengenalan awal teknologi tepat guna
(Purtomo, Ratih, \& Utomo, 2016a). Proses yang sederhana menimbulkan kehilangan masa udang rebon dari persiapan baku hingga menjadi produk terasi di setiap perlakuan proses yang diberikan. Peristiwa ini telah menjadi kajian di Bangka Belitung (Andriyani, Yuliati, \& Supriadi, 2014). 


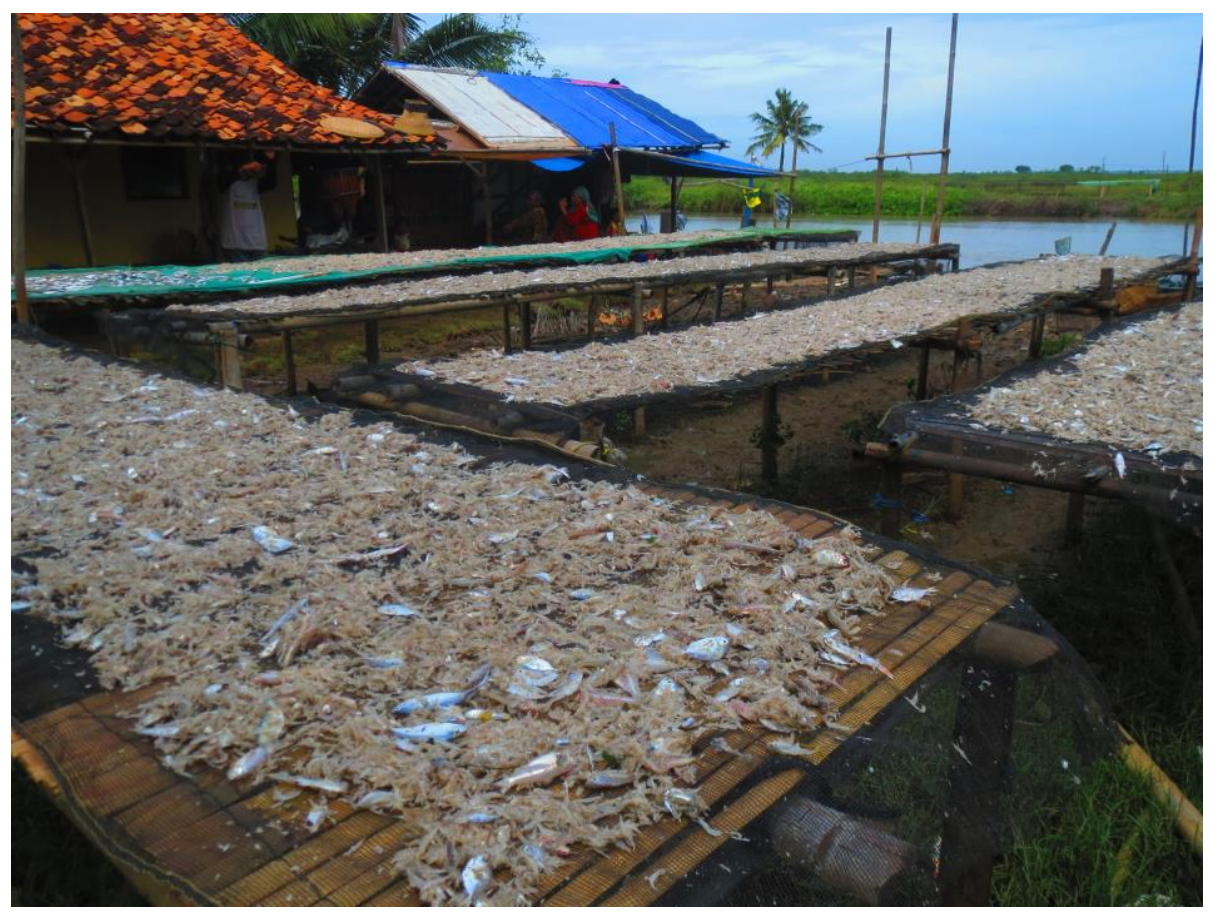

Gambar 2. Pemanfaatan lahan warga sebagai area penjemuran udang rebon

Keberadaan sinar matahari juga menjadi perhatian peneliti karena suhu lingkungan berubah seiring waktu. Perkiraan rendahnya kelembaban udara (diharapkan di bawah 60\%) akan memudahkan proses pengurangan kadar air di dalam bahan. Rendah-tingginya parameter proses mengakibatkan waktu pengeringan fluktuatif (1-2 minggu). Kala musim hujan, pengrajin tidak dapat melakukan produksi terasi secara maksimal.

Kebutuhan alat pengering modern menjadi langkah alternatif untuk mengatasi cuaca lingkungan. Selain itu, proses pengeringan juga membutuhkan ruangan yang mampu mengatasi sampel dari serangga sehingga higienitas produk terjaga (ruang pengering). Salah satu inovasi produksi terasi adalah alat pengering dengan sistem bertingkat (pengering rak tray dryer). Keberhasilan penggunaan alat tesebut telah dilakukan oleh beberapa peneliti pada bahan pangan yang salah satunya adalah rumput laut. Peneliti mampu meningkatkan suhu secara konstan di atas fluktuasi matahari (Fudholi et al., 2011b), dan peneliti lainnya telah sukses menonjolkan kemampuan zeolit sebagai agen dehumidified sehingga kelembaban udara menjadi lebih rendah (Mohamad Djaeni \& Sari, 2015). Kebutuhan energi untuk menghasilkan panas juga telah dimodifikasi peneliti lainnya yang awalnya berasal dari listrik berubah menjadi panel surya (Fudholi et al., 2011a).

Tray dryer mampu mengurangi dimensi luas penjemuran dan mengefisienkan kontak udara panas terhadap bahan. Sirkulasi udara di ruang pengering memberikan hasil yang tidak signifikan berbeda antara bahan di rak satu dan lainnya. Ilustrasi pengeringan di dalam tray dryer disajikan pada Gambar 3 berikut. Selanjutnya, proses pengeringan menjadi dapat ditentukan. Alat pengering tersebut mampu beroperasi hampir 24 jam tanpa memperhatikan ada tidaknya sinar matahari.

Penelitian ini dan peneliti lainnya juga belum menyajikan inovasi proses seperti kenaikan suhu, laju alir, dan penggunaan agen dehumidifikasi udara. Berbagai jenis pengering modern diterapkan dengan disesuaikan karakteristik bahan yang akan dikeringkan. Beberapa peneliti telah menerapkan pada bahan rumput laut, 
jagung (Mohamad Djaeni, Aishah, Nissaulfasha, \& Buchori, 2013), padi (Mochammad Djaeni et al., 2013), karaginan (Mohamad Djaeni, Sasongko, Prasetyaningrum, Jin, \& van Boxtel, 2012), (Mohamad Djaeni, Prasetyaningrum, \& Mahayana, 2012), spirulina (Prasetyaningrum \& Djaeni, 2012), serta lainnya. Peningkatan kajian parameter proses diarahkan pada skema penelitian selanjutnya. Pengenalan tray dryer dan adanya penelitian pendahuluan terhadap kegiatan petani terasi di sekitar pantai Ciparage merupakan salah satu upaya penanganan cuaca yang berubah-ubah. Para pengusaha dapat menghemat lahan penjemuran dan sikap memperhatikan keamanan pangan dari mulai bahan baku hingga produk siap dipasarkan.

Penelitian ini memaparkan penurunan kadar air bahan per waktu dan penampakan produk terasi dengan menghadirkan udara panas dari sinar matahari dan alat tray dryer. Kajian pengeringan terasi menggunakan pengering rak menjadi langkah alternatif untuk mengatasi pengeringan konvensional yang tidak memperhatikan kehigienisan produk terasi.

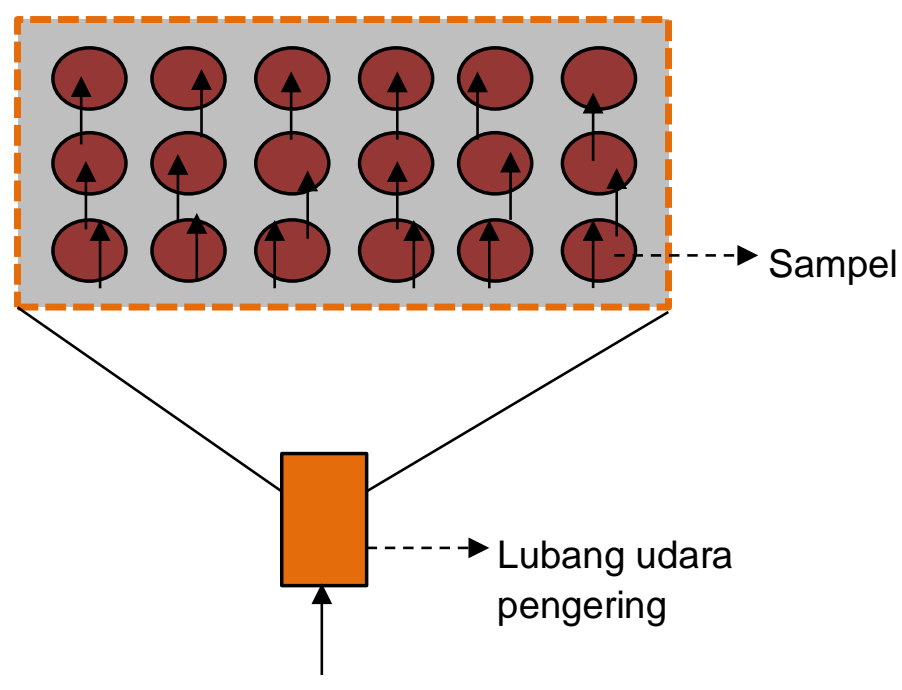

Aliran udara

Gambar 3. Sirkulasi udara panas pada ruang pengeringan tray dryer

\section{METODE}

Penelitian dilakukan di Laboratorium IImu Dasar Fakultas Teknik Universitas Singaperbangsa Karawang dan Laboratorium SMK Jayabeka I Karawang. Udang rebon merupakan bahan baku utama yang didapatkan dari TPI Ciparage Karawang. Proses pengeringan menggunakan tray dryer dengan rak sejumlah 6 buah (tingkat). Namun, penelitian ini memberdayakan rak kedua dan keempat selama proses pengeringan. Beban yang diberikan sebanyak $4 \mathrm{~kg}$ udang untuk setiap rak. Pengeringan udang rebon di bawah sinar matahari dilindungi kain kasa (layaknya rumahan) untuk mengurangi serangan lalat dan serangga lainnya. Hal ini juga diterapkan kepada pengrajin terasi di kota Pacitan yaitu pengadaan tirai penjemur sebelum digiling atau wareng sepanjang 50 $\mathrm{m}$ dengan lebar $250 \mathrm{~cm}$. Langkah ini bertujuan sebagai sarana penjemuran bahan terasi dengan jumlah yang lebih banyak dan bahan terasi sebelum digiling lebih bersih (Purtomo, Ratih, \& Utomo, 2016b).

Kuantitas bahan yang dijemur setara dengan alat pengering. Suhu operasi alat berada pada temperatur $40^{\circ} \mathrm{C}$ sebagai asumsi suhu rata-rata dari suhu sinar matahari (kegiatan dimulai dari pukul 10.00 WIB hingga 3,5 jam ke depan). Penurunan masa bahan diukur per 30 menit. Proses penjemuran kesatu hingga keenam hari 
mempertahankan durasi tersebut. Hari ke 12 merupakan penjemuran bahan baku, lalu hari ke 3-4 berupa bubur (penggilingan udang rebon), dan 2 hari selanjutnya sampel berbentuk lingkaran (telah tercetak, masing-masing 38 gram). Keseluruhan kegiatan selama enam hari tersebut umumnya memiliki tiga tahapan yaitu penggaraman, fermentasi, dan aging (Kim et al., 2014).

\section{HASIL DAN PEMBAHASAN}

Keseluruhan pengeringan dari udang rebon hingga terasi menggunakan waktu selama 210 menit selama enam hari. Penurunan kadar air dalam bahan disajikan pada Gambar 4 - 6. Kandungan air awal udang rebon (fresh) sebesar 90,80 $91,40 \%$ (basis basah, $X_{w}$ ) atau 9,87 10,63 (basis kering, $X_{D}$ ). Sedangkan, sampel tercetak memiliki kadar air awal sebesar 50,20 - 50,40\%. Kadar air produk kering terasi berkisar $\pm 35 \%$.

Gambar 6 menunjukkan bahwa penurunan masa sampel pada tray dryer pada akhir waktu hampir memiliki keadaan yang serupa dengan sinar matahari. Hal ini mengindikasikan bahwa kedua proses tidak memberikan hasil yang cukup signifikan berbeda. Penggunaan waktu penelitian berjalan lancar dan hadirnya sinar matahari mendukung kegiatan penelitian pembuatan terasi. Dugaan peneliti tidak meleset bahwa bulan Agustus merupakan durasi musim kemarau. Sebelumnya, peneliti melakukan eksperimen di bulan Februari hingga Maret. Kondisi lingkungan Karawang diselingi hujan dan panas sehingga proses pengeringan tidak berjalan sesuai harapan.

Sampel pada kondisi akhir berair di permukaan atas dan bawah produk (menggunakan alat pengering). Sampel tidak dibolak balik selama proses pengeringan dan penjemuran. Penampakan akhir dari produk terasi disajikan pada Gambar 7. Udara panas dari matahari menjadikan produk akhir terlihat lebih kering dari keluaran pengering rak. Secara fisik, output dari tray dryer lebih bagus. Hal ini disebabkan udara panas yang disirkulasikan merata dan tidak merusak sampel (kandungan protein) karena suhu yang diberikan berlangsung secara konstan. Produk terasi yang dimiliki wilayah lain juga menampilkan hasil yang terbeda. Setiap area memiliki proses produksi tersendiri (khas) dengan kualitas bahan baku yang pula (Kim et al., 2014). Peneliti mengadopsi proses produksi terasi dari warga lokal Karawang dengan harapan peneliti menemukan langkah peningkatan kualitas. Sebelumnya, warga belum mengujikan produk yang dihasilkan.

Petani lokal tidak mendasari penambahan bahan tambahan seperti garam selama proses produksi. Tujuan keberadaan garam kasar adalah penghilangan garam yang melekat pada bahan baku. Peneliti memberikan perlakuan awal bahan baku yaitu perendaman udang rebon selama 1 jam. Perbandingan yang diberikan antara bahan terhadap aquades adalah $1: 2$. Garam yang diberikan sebesar $2,5 \%$ terhadap aquades Proses tersebut merupakan pembuatan air laut buatan. Selain itu, garam pula membantu pengurangan aroma tidak sedap selama proses penghilangan kadar air.

Di sisi lain, proses penjemuran yang dilakukan petani menggunakan pare-pare terbuat dari anyaman bambu. Penumpukan bahan baku pada setiap rak tray dryer memiliki luas lahan yang lebih efisien dibandingkan pengeringan di bawah sinar matahari. Transfer panas di ruang pengering yang mendukung menjadikan opsi tray dryer lebih unggul. Proses pengeringan menerapkan dua konsep yaitu perpindahan panas dari udara ke bahan, dan perpindahan masa air yang dikeluarkan dari bahan. Hal ini ditunjukkan pada Gambar 8 berikut.

Aroma yang dihasilkan selama proses pengeringan untuk sinar matahari cukup mengganggu warga sekitar. Peralatan tray dryer dilengkapi dengan lubang untuk udara keluar dan lebih lanjut disambungkan dengan peralatan penyaringan udara. Hal ini telah dikaji untuk bangunan industri terasi Tuban yang menyematkan ventilasi berupa exhaust fan, blower, dan ventilator hepafiltrasi (RBD plasma) untuk polutan terasi di dalam ruangan (Rahayu, Purwono, \& Sujudwijono, 2015). 


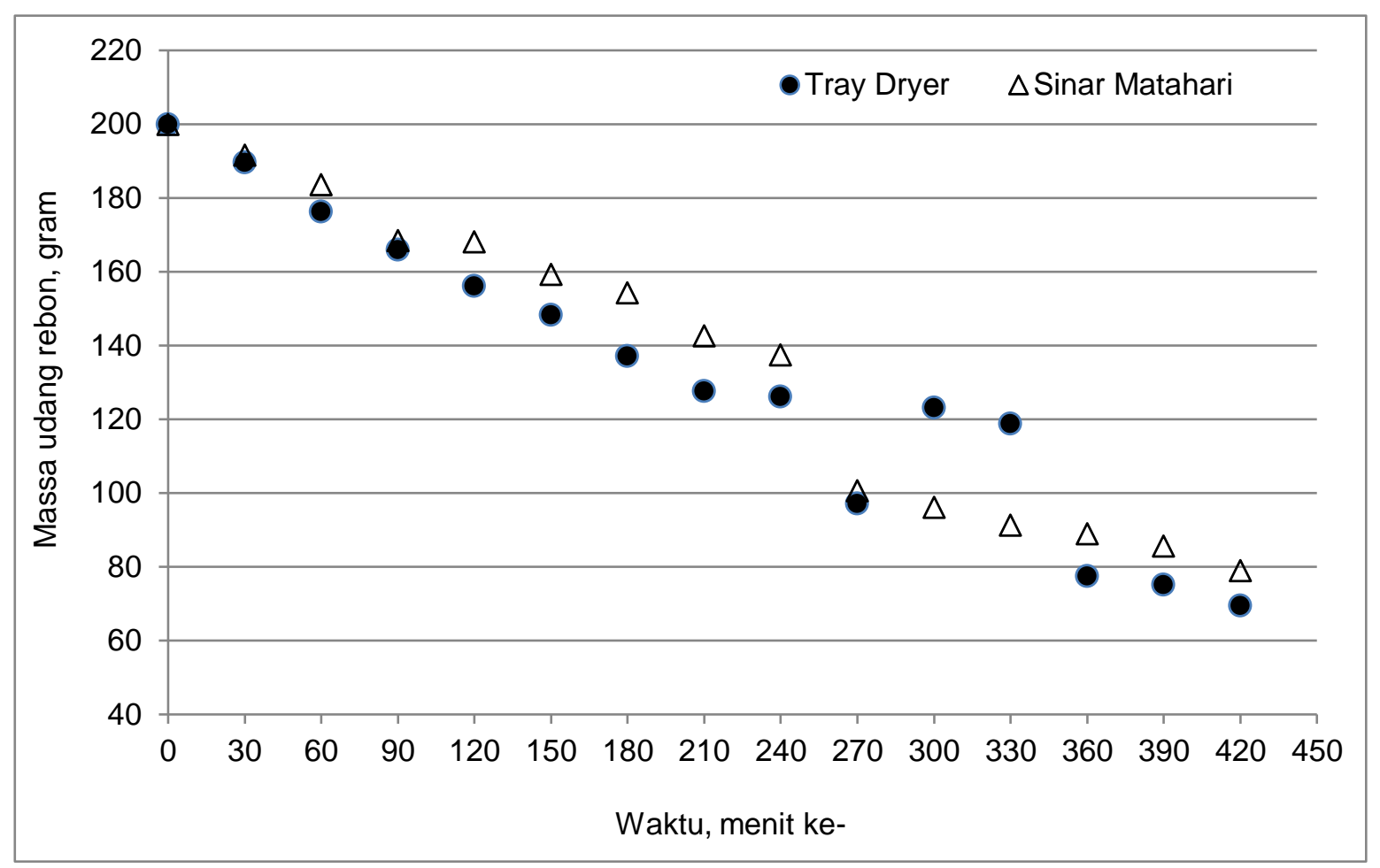

Gambar 4. Penurunan kadar air bahan baku udang rebon

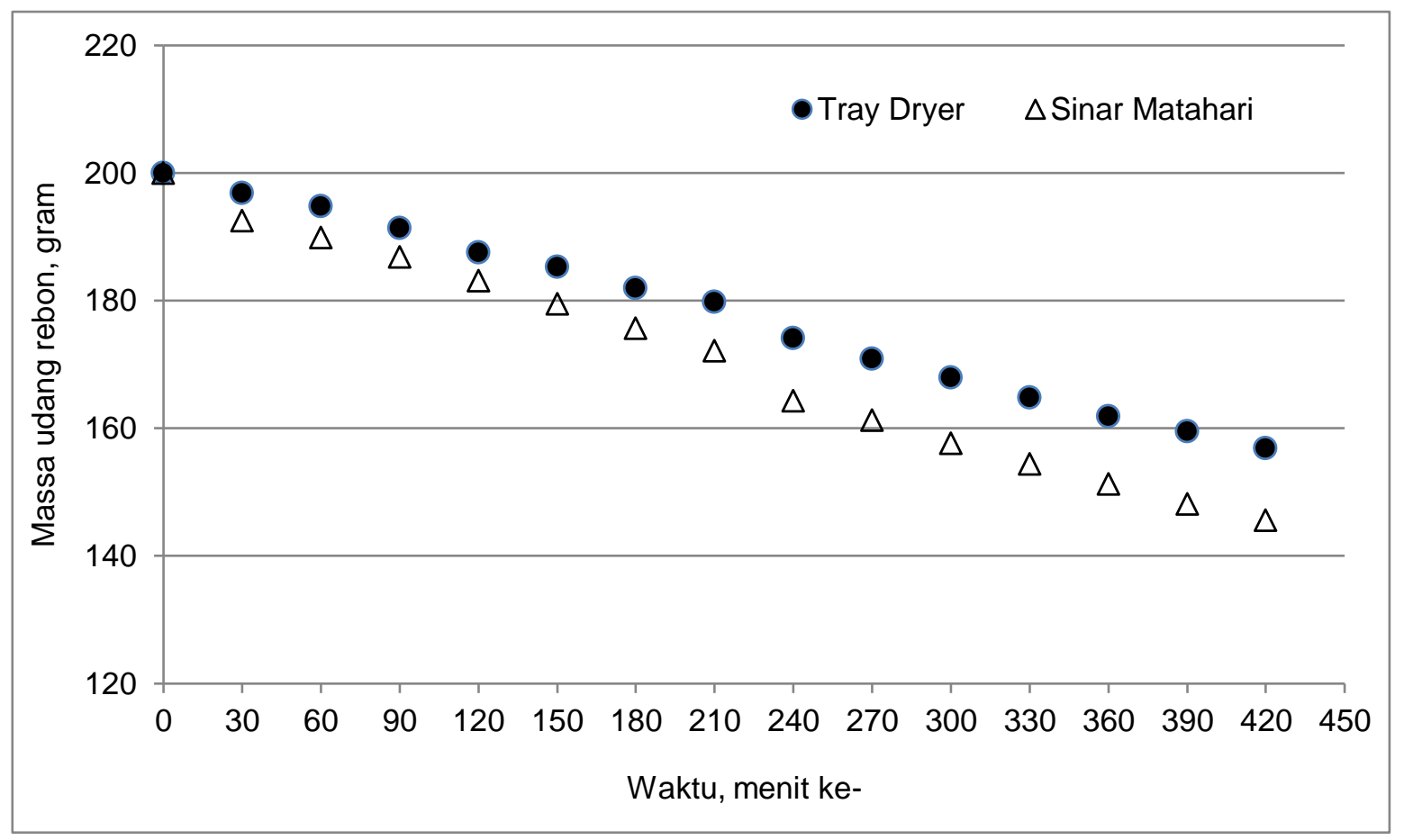

Gambar 5. Penurunan kadar air bubur udang rebon 


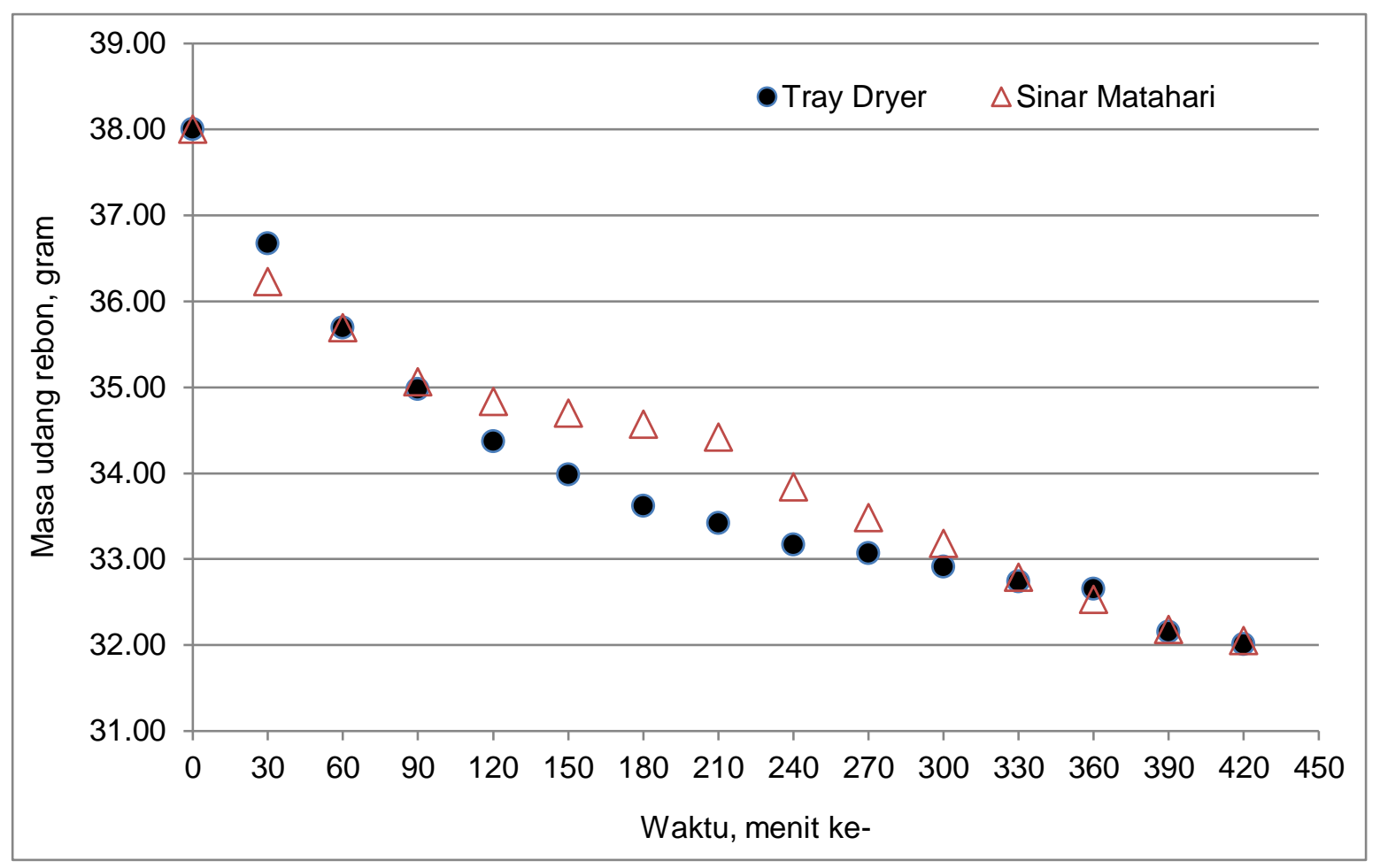

Gambar 6. Penurunan kadar air terasi udang rebon

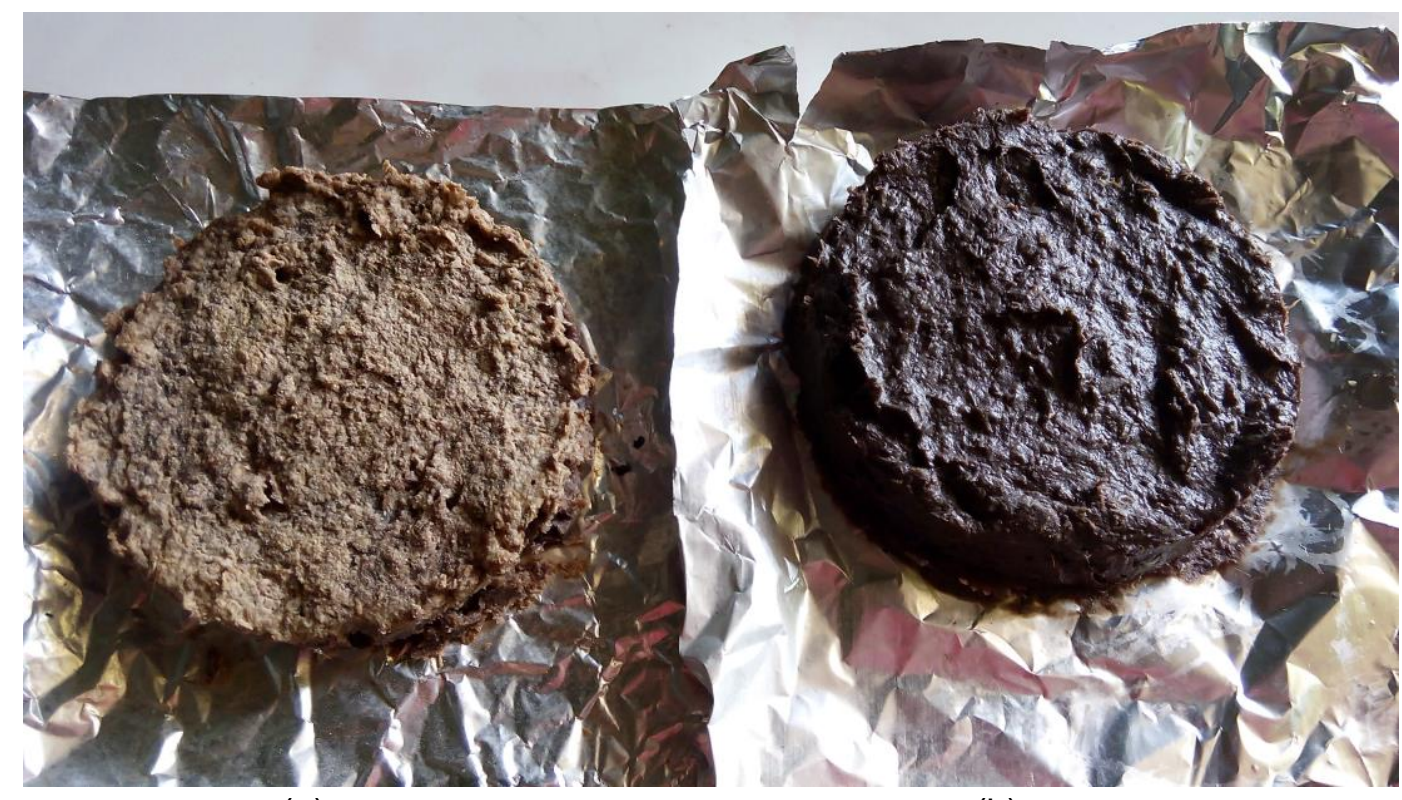

(a)

(b)

Gambar 7. Penampakan output menggunakan : (a) sinar matahari; (b) pengering rak 


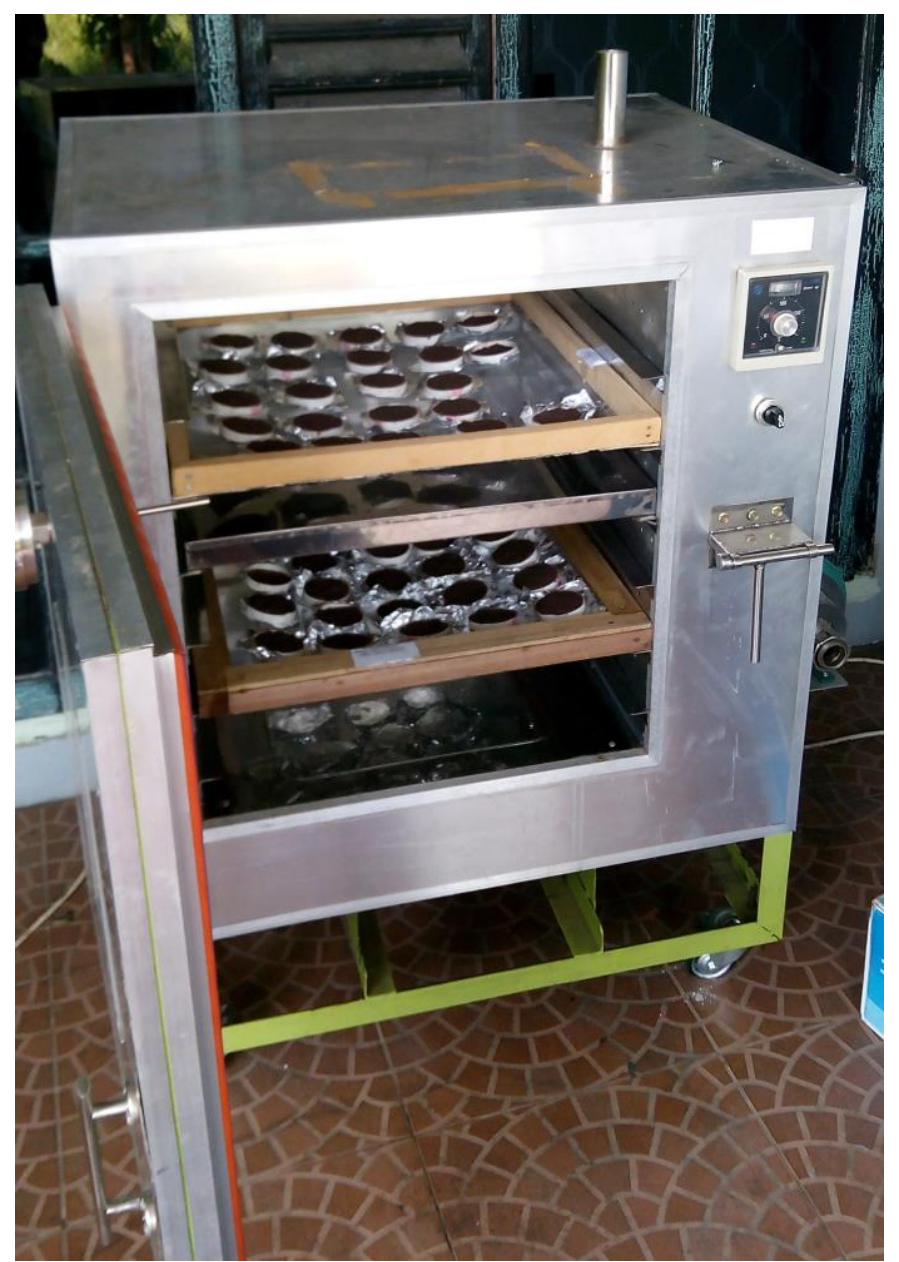

Gambar 8. Proses pengeringan terasi menggunak tray dryer

\section{SIMPULAN}

Penggunaan pengering rak menyajikan penampakan produk yang lebih bagus dari penyinaran matahari meskipun tidak ada perbedaan secara nyata mengenai penurunan masa bahan per waktu. Kesulitan penjemuran di lapangan terbuka karena cuaca lingkungan berubah-ubah dan bahan tersebut mengundang kehadiran beberapa serangga. Hal ini mengakibatkan adanya belatung pada bagian permukaan bahan. Pola pembuatan terasi yang bersih diharapkan oleh para konsumen. Selanjutnya, empat rak yang belum termanfaatkan dapat dijadikan langkah pengoptimalan penggunaan tray dyer dan menjadi poin lebih dibandingkan dengan pengeringan konvensional.

\section{UCAPAN TERIMA KASIH}

Tim penulis mengucapkan terima kasih kepada Lembaga Penelitian dan Pengabdian kepada Masyarakat Universitas Singaperbangsa Karawang dengan Surat Perjanjian Penugasan Hibah Penelitian bagi Dosen Unsika Nomor : 0891/SP2H/UN64/V/2017. Tim peneliti juga terbantu atas dukungan dari Laboratorium SMK Jayabeka I Karawang (khususnya pak Lalan) yang telah membantu kelancaran kegiatan pengovenan sampel. Spiritual dan moril dari para mahasiswa Teknik Elektro Kelas A dan B Angkatan 2015 (pembuatan terasi, khususnya kepada Amalina Almas, Anggit Satrio Suwana dan cs, serta Eki Bagus Susilo cs). Kemudian, kepala TPI Ciparage (pak Khalamullah) membantu kelancaran penyaluran ketersediaan bahan baku udang rebon. 


\section{DAFT AR PUSTAKA}

Andriyani, E. A., Yuliati, K., \& Supriadi, A. (2014). Efisiensi dan Identifikasi Loss pada Proses Pengolehan Terasi Udang Rebon (Acetes sp) di Desa Belo Laut Kecamatan Muntok Bangka Belitung. Jurnal Teknologi Hasil Perikanan, 1(1), 26-40.

Djaeni, M., Aishah, N., Nissaulfasha, H., \& Buchori, L. (2013). Corn Drying with Zeolite in the Fluidized Bed Dryer under Medium Temperature. IPTEK, 24(2), 1.

Djaeni, M., Ayuningtyas, D., Asiah, N., Hargono, H., Ratnawati, R., Wiratno, W., \& Jumali, J. (2013). Paddy drying in mixed adsorption dryer with zeolite: Drying rate and time estimation. Reaktor, 14(3), 173-178.

Djaeni, M., Prasetyaningrum, A., \& Mahayana, A. (2012). Pengeringan Karaginan dari Rumput Laut Eucheuma cottonii pada Spray Dryer Menggunakan Udara yang Didehumidifikasi dengan Zeolit Alam. Momentum, 8(2). Retrieved from http://publikasiilmiah.unwahas.ac.i $\mathrm{d} /$ index.php/MOMENTUM/article/vi ew/428

Djaeni, M., \& Sari, D. A. (2015). Low Temperature Seaweed Drying Using Dehumidified Air. Procedia Environmental Sciences, 23, 2-10. https://doi.org/10.1016/j.proenv.20 15.01 .002

Djaeni, M., Sasongko, S. B., Prasetyaningrum, A., Jin, X., \& van Boxtel, A. J. (2012). Carrageenan Drying with Dehumidified Air : Drying Characteristics and Product Quality. International Journal of Food Engineering, 8(3). https://doi.org/10.1515/15563758.2682
Fudholi, A., Othman, M. Y., Ruslan, M. H., Yahya, M., Zaharim, A., \& Sopian, K. (2011a). Design and Testing of Solar Dryer for Drying Kinetics of Seaweed in Malaysia. Recent Research in Geography, Geology, Energy, Environment and Biomedicine, 119-124.

Fudholi, A., Othman, M. Y., Ruslan, M. H., Yahya, M., Zaharim, A., \& Sopian, K. (2011b). The Effects of Drying Air Temperature and Humidity on Drying Kinetics of Seaweed. Recent Research in Geography, Geology, Energy, Environment and Biomedicine, 129-133.

Kim, Y.-B., Choi, Y.-S., Ku, S.-K., Jang, D.-J., Ibrahim, H. H. binti, \& Moon, K. B. (2014). Comparison of Quality Characteristics Between Belacan from Brunei Darussalam and Korean Shrimp Paste. Journal of Ethnic Foods, 1(1), 19-23. https://doi.org/10.1016/j.jef.2014.1 1.006

Maflahah, I. (2013). Kajian Potensi Usaha Pembuatan Terasi Udang Studi Kasus Desa Bantelan Kecamatan Batu Putih Kabupaten Sumenep. Agrointek, 7 No 2, 99-102.

Ma'ruf, M., Sukarti, K., Purnamasari, E., \& Sulistianto, E. (2013). Penerapan Produksi Bersih pada Industri Pengolahan Terasi Skala Rumah Tangga. Jurnal Ilmu Perikanan Tropis, 18(2), 84-93.

Prasetyaningrum, A., \& Djaeni, M. (2012). Drying Spirulina with Foam Mat Drying at Medium Temperature. Internatiol Journal of Science and Engineering, 3(2), 1-3.

Purtomo, T., Ratih, I. A. B., \& Utomo, D. B. (2016a). IbM elompok Usaha Rumah Tangga Terasi Rebon di Lingkungan Pantai Teleng Kota Pacitan. JPM17: Jurnal Pengabdian Masyarakat, 2(01), 19-28. 
Purtomo, T., Ratih, I. A. B., \& Utomo, D. B. (2016b). IbM Kelompok Usaha Rumah Tangga Terasi Rebon di Lingkungan Pantai Teleng Kota Pacitan. JPM17, 2(01). Retrieved from http://jurnal.untagsby.ac.id/index.php/jpm17/article/vi $\mathrm{ew} / 781$

Rahayu, R. D., Purwono, E. H., \& Sujudwijono, N. (2015). Perancangan Bangunan Industri Terasi di Tuban. Jurnal Mahasiswa Jurusan Arsitektur, 3(1). Retrieved from

http://arsitektur.studentjournal.ub.a c.id/index.php/jma/article/view/69

Sulistiyono, S. T. (2014). Mengenal Sistem Pengetahuan, Teknologi, dan Ekonomi Nelayan Pantai Utara Jawa. AGASTYA: Jurnal Sejarah Dan Pembelajarannya, 4(02), 124. 